\title{
Effectiveness of an Instructional Program on Nurses' Knowledge concerning Preparation of Patients for Gastro-colonoscopy in Al- Hussein Teaching Hospital at Al- Nasiriyah City
}

\author{
Sajjad S. Salman, ${ }^{1,}$ Dr. Huda B. Hassan ${ }^{2}$ \\ ${ }^{1}$ (Sajjad Sadiq Salman / BSC. in Nursing/ Refai General Hospital \\ ${ }_{2}^{2}$ (Dr. Huda Baker Hassan/PhD in Nursing/College of Nursing, University of Baghdad, Iraq)
}

\begin{abstract}
Objective: The study aims to evaluate the effectiveness of an instructional program on nurses knowledge concerning preparation of patients for gastro-colonoscopy.

Methodology: A quazi-experimental study was carried out at endoscopy units in Al-Hussein Teaching Hospital at Al- Nasiriyah City starting from (27 September 2016) to (15 May 2017). A purposive (non-probability) sample of 50 nurses was divided into two groups, case group consisted of 25 nurses who exposed to instructional program and control group consisted of 25 nurses were not exposed to the program on nurses who working in Al-Hussein Teaching Hospital. The questionnaire consists of two parts, the first part is related to sociodemographic data of nurses which as 8 items and the second part is related to nurses' knowledge which consists of 11 domains dealing 91 items. A descriptive statistical analysis was applied (frequency, and percentage) and inferential analysis (ANOVA) were used to analysis the data. Results: The findings of the present study indicated that the nurses knowledge for case group which exposed to instructional program were improved at post test for all domains which as 53.6\% of nurses responses was wrong at pre test to $70.8 \%$ write answer, there were no statistically significant differences between nurses' knowledge and level of education, and there were significant relationships between effectiveness of instructional program on case group and their experiences of them in nursing field and their experiences in endoscopy unit.

Conclusion: The study concluded that there was effectiveness of instructional program on nurses Knowledge concerning Preparation of Patients for Gastro-colonoscopy in Al-Hussein Teaching Hospital at Al-Nasiriyah City.

Recommendations: The study recommends great emphasis should be directed toward the educational aspects at endoscopy unit by providing educational posters, guidelines, pamphlets and manuals, encourage engaging nurses by ministry of health for training course concerning preparation of patients for endoscopy, and activating the promotion law through the participation of nurses in continuing education courses.
\end{abstract}

Keywords: Instructional Program, Preparation of Patients, Knowledge, Gastro-colonoscopy

\section{Introduction}

Gastrointestinal endoscopy is performed more and more frequently due to their clear diagnostic benefits and therapeutic application advantages. Gastrointestinal endoscopy includes gastroscopy, sigmoidoscopy and colonoscopy. It may be inserted through the mouth or anus, depending on the area of interest. Gastroscopy is an examination of the lining of the esophagus, stomach and upper duodenum with a small camera (flexible endoscope) which is inserted down the throat. A colonoscopy is an internal examination of the colon (large intestine) and rectum, using an instrument called a colonoscope. The colonoscope has a small camera attached to a flexible tube. Unlike sigmoidoscopy, which can only reach the lower third of the colon, colonoscopy examines the entire length of the colon. If necessary, the doctor will use the endoscope to perform a biopsy, which involves collecting tiny samples of tissue for examination with a microscope ${ }^{(1)}$. Colonoscopy is currently considered the gold standard for the investigation of large bowel pathology. Bowel preparation prior to colonoscopy is mandatory to provide an adequately visualized clean colon, which is essential to achieve effective diagnostic and potentially therapeutic objectives ${ }^{(2)}$. Endoscopy is provided by a range of medical practitioners (including physicians and surgeons) and a very small number of registered nurses. All clinicians performing endoscopy in the public health sector must be properly endorsed by the Health Service Chief Executive (HSCE) in which they operate ${ }^{(3)}$. Upper endoscopy is used to determine the cause of: abdominal pain nausea/vomiting swallowing difficulties gastric reflux unexplained weight loss anemia bleeding in the upper digestive tract. Upper endoscopy is also used to remove trapped objects (including food), treat conditions, such as bleeding ulcers and biopsy tissue. Biopsies can be taken to determine sites of infection, to test the 
functioning of the small bowel and to diagnose abnormal tissue, including conditions, such as celiac disease and cancerous lesions ${ }^{(4)}$.

The most common indications for colonoscopies in previous studies have been gastrointestinal blood loss and anaemia, change in bowel habits and abdominal pain ${ }^{(5)}$. A relevant lesion was found in over half of the examinations when indications were either anemia or rectal bleeding. If the indication for examination was a change in bowel habit or weight loss a relevant finding was found in $26 \%$ of cases ${ }^{(6)}$. Colonoscopy is considered abetter-screening method for colon cancer compared with sigmoidoscopy because identifies proximal lesions ${ }^{(7)}$.

\section{Objectives of The Study}

The study aims to:

1- Find out the effectiveness of the instructional program on nurses' knowledge toward preparation for Gastrocolonoscopy

2- Find out the relationship between the nurses' demographic characteristics and effectiveness of instructional program

3- Compare between case and control group regarding effectiveness of instructional program

\section{Methodology}

Design of the Study: A quasi-experimental design study is carried out through the application of pre-test and post-test approach for the case and control groups, from the period of, 27th September 2016 to the 31th June 2017

Setting of the Study: The present study is carried out in the medical and surgical wards at Al-Huessin Teaching Hospital in Nasrrhyia City.

Sample of the Study: A purposive (non-probability) sample of (50) nurses who work in endoscopy unit, medical and surgical ward at Al-Hussein Teaching hospital in Nassrhyia city. The sample is divided two groups which is case and control group.

Instrument: consists of two parts:

Part I: Self-administration related to socio-demographic characteristic, which as age, gender, marital status, level of education, years of experience, and participant in training course

Part II: pre and posttest questionnaire for nurses' knowledge concerning preparation of patient for gastrocolonoscopy The items knowledge was composed of (91) item divided into 11 domains which as; Nurses' knowledge related to the endoscopy it domain (8) items; Nurses' knowledge related the qualifications and duties of the health team working in the endoscopy unit domain (12) items; Nurses 'knowledge related to indication of gastroscopy domain (9) items; Nurses' knowledge related to the preparation of a patient to the of endoscopy domain (5) items; Nurses' knowledge related to the steps endoscopy domain (16) items; Nurses' knowledge related to Patient care after gastroscopy domain (7) items; Nurses' knowledge related complications of gastroscopy domain (5) items; Nurses' knowledge related to indications of colonoscopy domain (4) items.

Nurses' knowledge related to steps for making colonoscopy domain (8) items; Nurses' knowledge related to nursing care during a colonoscopy domain (9) items; Nurses' knowledge related to nursing care after colonoscopy procedure domain (5) items.

Validity and Reliability: The content validity of the instructional program and the study instruments are established through a panel of (9) experts.,

Statistical Analysis: The data have been analyzed through the application of: descriptive frequency, percentages; mean of scores; and the inferential analysis that Include Analysis of variance, and the researcher used the SPSS version 20 to analysis of data.

IV. Results

Table (1): Distribution of the Study Sample by Socio- Demographic for (Case and Control Group) No= 20 nurses

\begin{tabular}{|c|c|c|c|c|c|}
\hline \multirow{2}{*}{ Variables } & \multirow{2}{*}{ Classification } & \multicolumn{2}{|c|}{ Case Group } & \multicolumn{2}{|c|}{ Control Group } \\
\hline & & Frequency & Percent & Frequency & Percent \\
\hline \multirow[t]{7}{*}{ Age } & $20-24$ & 4 & 20.0 & 6 & 30.0 \\
\hline & $25-29$ & 4 & 20.0 & 7 & 35.0 \\
\hline & $30-34$ & 6 & 30.0 & 3 & 15.0 \\
\hline & $35-39$ & 4 & 20.0 & 2 & 10.0 \\
\hline & $40-44$ & 1 & 5.0 & 1 & 5.0 \\
\hline & $45 \geq$ & 1 & 5.0 & 1 & 5.0 \\
\hline & $\bar{x} \mp$ S. D. & 31.15 & 6.651 & 26.20 & 363 \\
\hline \multirow[t]{2}{*}{ Gender } & Male & 13 & 65.0 & 11 & 55.0 \\
\hline & Female & 7 & 35.0 & 9 & 45.0 \\
\hline
\end{tabular}




\begin{tabular}{|c|c|c|c|c|c|}
\hline & Total & 20 & 100.0 & 20 & 100.0 \\
\hline \multirow[t]{3}{*}{ Marital status } & Single & 4 & 20.0 & 5 & 25.0 \\
\hline & Married & 15 & 75.0 & 15 & 75.0 \\
\hline & Widowed & 1 & 5.0 & 0 & 0.0 \\
\hline \multirow[t]{3}{*}{ Level of Education } & $\begin{array}{l}\text { Secondary school } \\
\text { Nursing }\end{array}$ & 8 & 40.0 & 16 & 80.0 \\
\hline & Nursing Institute & 10 & 50.0 & 0 & 0.0 \\
\hline & College of Nursing & 2 & 10.0 & 4 & 20.0 \\
\hline \multirow[t]{3}{*}{ Monthly income } & Enough & 7 & 35.0 & 7 & 35.0 \\
\hline & Barely Enough & 10 & 50.0 & 13 & 65.0 \\
\hline & Not Enough & 3 & 15.0 & 0 & 0.0 \\
\hline \multirow[t]{4}{*}{ Years of experience in the field of Nursing } & 1-5 years & 6 & 30.0 & 2 & 10.0 \\
\hline & 6-10 years & 6 & 30.0 & 8 & 40.0 \\
\hline & 11-15 years & 4 & 20.0 & 7 & 35.0 \\
\hline & 16 years and more & 4 & 20.0 & 3 & 15.0 \\
\hline \multirow[t]{4}{*}{ years of experience in the endoscopy unit } & $1-5$ years & 7 & 35.0 & 6 & 30.0 \\
\hline & 6-10 years & 3 & 15.0 & 9 & 45.0 \\
\hline & 11-15 years & 5 & 25.0 & 2 & 10.0 \\
\hline & 16 years and more & 5 & 25.0 & 3 & 15.0 \\
\hline \multirow{2}{*}{$\begin{array}{l}\text { participated in a training course } \\
\text { related to gastro-colonoscopy }\end{array}$} & Yes & 8 & 40.0 & 11 & 55.0 \\
\hline & No & 12 & 60.0 & 9 & 45.0 \\
\hline
\end{tabular}

The results of table 1 revealed that $30 \%$ of nurses in the case group at age group (30-34 years) while (35\%) of nurses in the control group at age group(25-29 years), 65\% of nurses in the case group were males and $55 \%$ of nurses in the a control group were males, $75 \%$ of the study sample (case and control groups) were married, $55 \%$ of nurses in the case group and $65 \%$ of nurses in the control group are barely enough income. Concerning level of education, most of nurses $50 \%$ of case group were institute graduated, while $80 \%$ of control group graduated from secondary school nursing. In relation to year of experiences in a field of nursing $30 \%$ of a case group have 1-10 years, $40 \%$ of control group have 6-10 years of experience in the field of nursing. Concerning to the years of experience in the endoscopy $35 \%$ of a case group 1-5 years, $45 \%$ of a control group have 6-10years of experience in the endoscopy unit, $40 \%$ of a case group was participate in a training course related to gastro-endoscopy, and $55 \%$ of a control group was participate in a training course.

Table (2): Pre and Post Nurses Responses for case group regarding Instructional Program concerning Nurses Knowledge about Preparation of Patients for Gastro-Colonoscopy

\begin{tabular}{|c|c|c|c|c|c|c|}
\hline \multirow{2}{*}{$\begin{array}{c}\text { No. } \\
\text { Domai } \\
\text { n }\end{array}$} & \multirow[b]{2}{*}{$\begin{array}{l}\text { Main Domains Related to Nurses' Knowledge } \\
\qquad \mathbf{n}=0\end{array}$} & \multirow{2}{*}{$\begin{array}{c}\text { No. } \\
\text { Item } \\
\mathrm{s}\end{array}$} & \multicolumn{2}{|c|}{ Pre -Case } & \multicolumn{2}{|c|}{ Post -Case } \\
\hline & & & I Know & $\begin{array}{l}\text { I don't } \\
\text { Know }\end{array}$ & $\begin{array}{c}\text { I } \\
\text { Know }\end{array}$ & $\begin{array}{l}\text { I don't } \\
\text { Know }\end{array}$ \\
\hline $\mathbf{1}$ & Nurses Knowledge about Gastro-Colonoscopy & 8 & $46.25 \%$ & $53.75 \%$ & $\begin{array}{c}76.25 \\
\%\end{array}$ & $23.75 \%$ \\
\hline 2 & $\begin{array}{l}\text { Nurses Knowledge about qualifications of health team } \\
\text { working in the endoscopy unit }\end{array}$ & 12 & $53.7 \%$ & $46.3 \%$ & $80.0 \%$ & $20.0 \%$ \\
\hline 3 & Nurses Knowledge about reasons of gastro copy & 9 & $54.4 \%$ & $45.6 \%$ & $69.4 \%$ & $30.6 \%$ \\
\hline 4 & $\begin{array}{l}\text { Nurses Knowledge related preparation of a patient for } \\
\text { endoscopy }\end{array}$ & 8 & $62.5 \%$ & $37.5 \%$ & $69.4 \%$ & $30.6 \%$ \\
\hline 5 & Knowledge of nurses about the steps of endoscopy & 16 & $57.5 \%$ & $42.5 \%$ & $62.8 \%$ & $37.2 \%$ \\
\hline 6 & Nurses Knowledge about Patient care after gastroscopy & 7 & $48.6 \%$ & $51.4 \%$ & $58.6 \%$ & $41.4 \%$ \\
\hline 7 & Nurses Knowledge about the complications of gastroscopy & 5 & $56.0 \%$ & $44.0 \%$ & $61.0 \%$ & $39.0 \%$ \\
\hline 8 & Nurses Knowledge about the reasons of colonoscopy & 4 & $55.0 \%$ & $45.0 \%$ & $67.5 \%$ & $32.5 \%$ \\
\hline 9 & Nurses Knowledge about steps of colonoscopy & 8 & $54.4 \%$ & $45.6 \%$ & $\begin{array}{c}76.25 \\
\%\end{array}$ & $23.75 \%$ \\
\hline 10 & Nurses Knowledge about Nursing care during a colonoscopy & 9 & $47.8 \%$ & $52.2 \%$ & $74.4 \%$ & $25.6 \%$ \\
\hline 11 & $\begin{array}{l}\text { Nurses Knowledge about nursing care for patients after a } \\
\text { colonoscopy procedure }\end{array}$ & 5 & $51.0 \%$ & $49.0 \%$ & $85.0 \%$ & $15.0 \%$ \\
\hline 12 & Total domains of Nurses' Knowledge & 91 & $53.6 \%$ & $46.4 \%$ & $\mathbf{7 0 . 8 \%}$ & $29.2 \%$ \\
\hline
\end{tabular}

The results of table 2 presented that the nurses knowledge for case group which exposed to instructional program were improved at post test for all domains which as $53.6 \%$ of nurses' responses for pretest to $70.8 \%$ at posttest. 
Table (4): Nurses Responses for (Pre- Case and Pre-Control) regarding Instructional Program concerning Nurses Knowledge about Preparation of Patients for Gastro-Colonoscopy

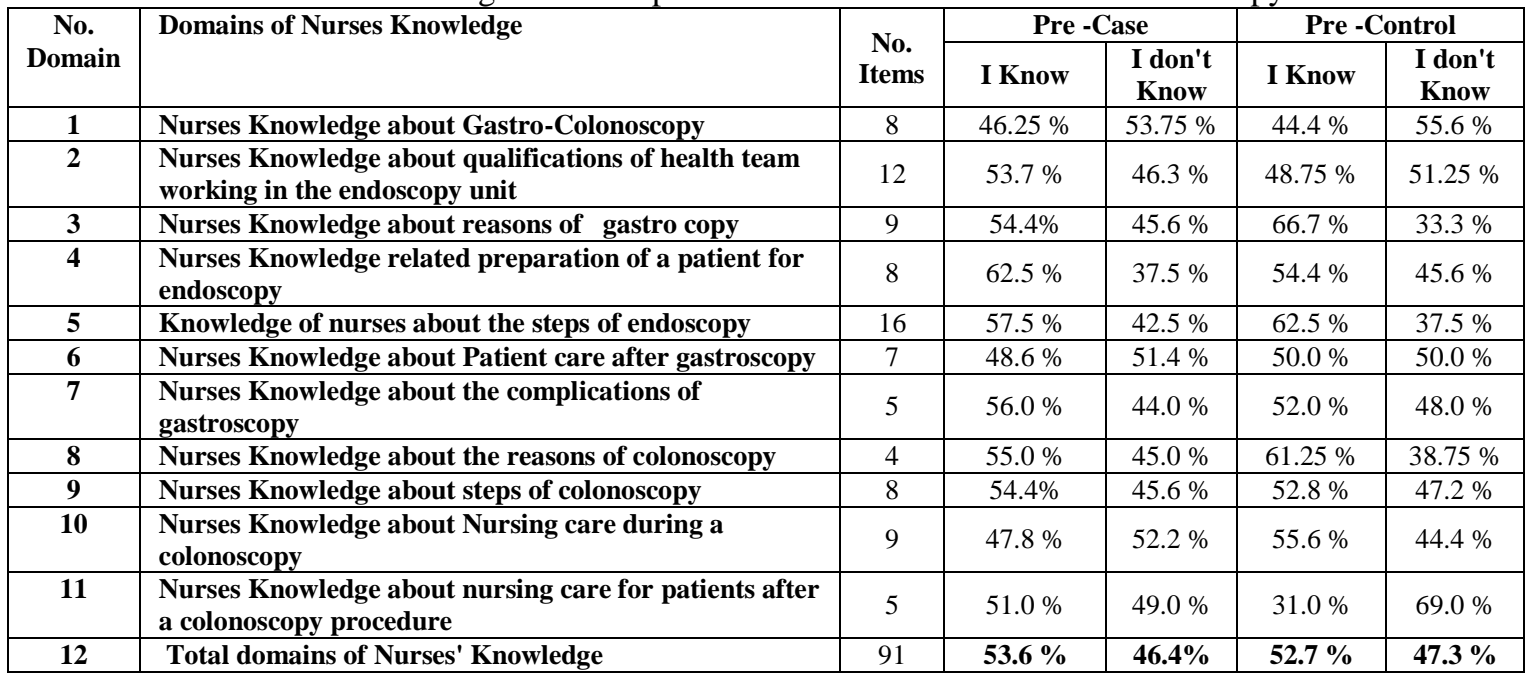

Table 4 shows that the nurse's responses for pre-case and pre control for total domains about their knowledge toward preparation of patients for gastro-colonoscopy were nearest level of knowledge which of $46.4 \%$ don't know for case, and $47.3 \%$ don't know for control group before exposed the instructional program on case group.

Table (5): Nurses Responses for (Post-Case and Post Control) regarding Instructional Program concerning Nurses Knowledge about Preparation of Patients for Gastro-Colonoscopy

\begin{tabular}{|c|c|c|c|c|c|c|}
\hline \multirow[b]{2}{*}{$\begin{array}{l}\text { No. } \\
\text { Domain }\end{array}$} & \multirow[b]{2}{*}{ Domains of Nurses Knowledge } & \multirow[b]{2}{*}{$\begin{array}{l}\text { No. } \\
\text { Items }\end{array}$} & \multicolumn{2}{|c|}{ Post -Case } & \multicolumn{2}{|c|}{ Post- Control } \\
\hline & & & I Know & $\begin{array}{l}\text { I don't } \\
\text { Know }\end{array}$ & $\begin{array}{c}\text { I } \\
\text { Know }\end{array}$ & $\begin{array}{l}\text { I don't } \\
\text { Know }\end{array}$ \\
\hline 1 & Nurses Knowledge about Gastro-Colonoscopy & 8 & $76.25 \%$ & $23.75 \%$ & $\begin{array}{c}53.25 \\
\%\end{array}$ & $46.75 \%$ \\
\hline 2 & $\begin{array}{l}\text { Nurses Knowledge about qualifications of health team working } \\
\text { in the endoscopy unit }\end{array}$ & 12 & $80.0 \%$ & $20.0 \%$ & $46.5 \%$ & $53.5 \%$ \\
\hline 3 & Nurses Knowledge about reasons of gastro copy & 9 & $69.4 \%$ & $30.6 \%$ & $58.9 \%$ & $41.1 \%$ \\
\hline 4 & Nurses Knowledge related preparation of a patient for endoscopy & 8 & $69.4 \%$ & $30.6 \%$ & $54.3 \%$ & $45.7 \%$ \\
\hline 5 & Knowledge of nurses about the steps of endoscopy & 16 & $62.8 \%$ & $37.2 \%$ & $66.7 \%$ & $33.3 \%$ \\
\hline 6 & Nurses Knowledge about Patient care after gastroscopy & 7 & $58.6 \%$ & $41.4 \%$ & $59.7 \%$ & $40.3 \%$ \\
\hline 7 & Nurses Knowledge about the complications of gastroscopy & 5 & $61.0 \%$ & $39.0 \%$ & $71.9 \%$ & $28.1 \%$ \\
\hline 8 & Nurses Knowledge about the reasons of colonoscopy & 4 & $67.5 \%$ & $32.5 \%$ & $63.0 \%$ & $37.0 \%$ \\
\hline 9 & Nurses Knowledge about steps of colonoscopy & 8 & $76.25 \%$ & $23.75 \%$ & 51.6 & $48.4 \%$ \\
\hline 10 & Nurses Knowledge about Nursing care during a colonoscopy & 9 & $74.4 \%$ & $25.6 \%$ & $58.0 \%$ & $42.0 \%$ \\
\hline 11 & $\begin{array}{l}\text { Nurses Knowledge about nursing care for patients after a } \\
\text { colonoscopy procedure }\end{array}$ & 5 & $85.0 \%$ & $15.0 \%$ & $33.0 \%$ & $67.0 \%$ \\
\hline 12 & Total domains of Nurses' Knowledge & 91 & $70.8 \%$ & $29.2 \%$ & $56.5 \%$ & $43.5 \%$ \\
\hline
\end{tabular}

Table 5 shows that the nurse's responses for post case which exposed to instructional program and post control for total domains about their knowledge toward preparation of patients for gastro-colonoscopy were improved case group knowledge which as $70.8 \%$, comparison to knowledge of control group. 


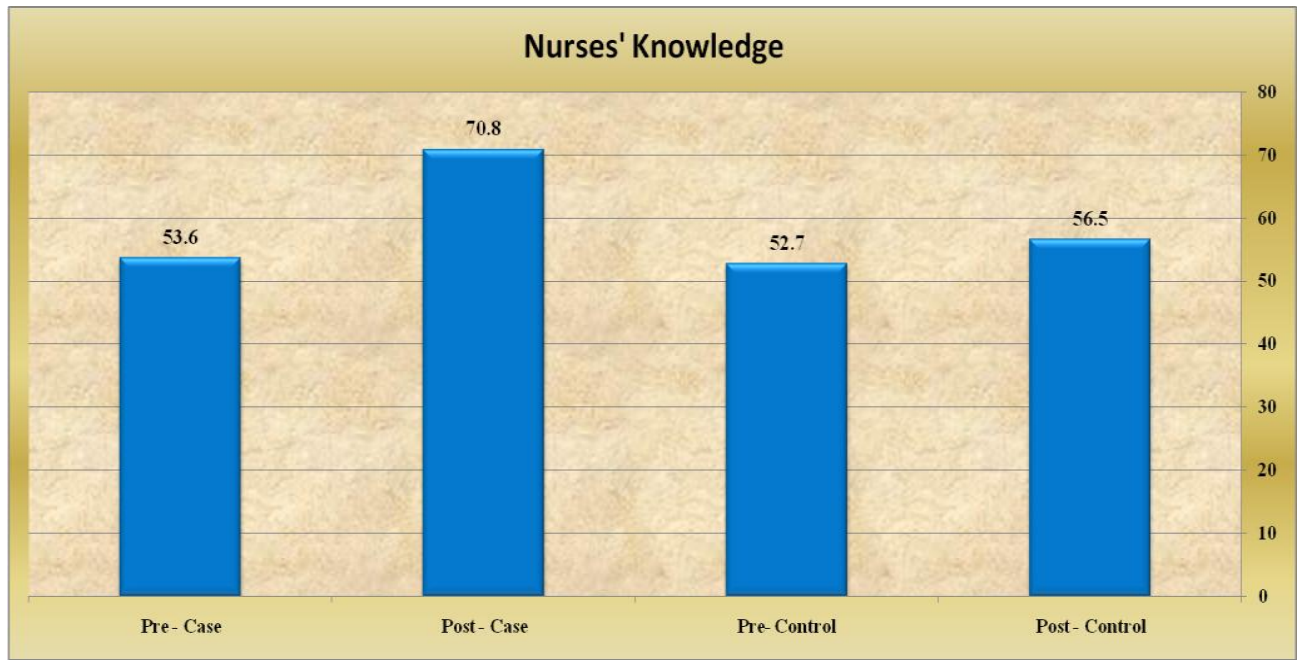

Figure 1: Nurses Responses at Pre-and Post-test for case and control Groups

Figure 1 demonstrate the level of nurses' knowledge for case and control groups at pre and posttest which revealed that the effectiveness of program were clear at post test for case group which exposed the instructional program concerning preparation of patients for gastero-colonoscopy.

Table 10: Association between Effectiveness of Instructional Program and level of Education of case Group

\begin{tabular}{|c|c|c|c|c|c|c|c|}
\hline \multicolumn{2}{|c|}{$\begin{array}{c}\text { Level of education } \\
\text { Total domains }\end{array}$} & $\mathbf{N}$ & Mean & SD & & $\mathbf{F}$ & $\begin{array}{c}\text { Sig. } \\
\mathbf{P} \geq \mathbf{0 . 0 5}\end{array}$ \\
\hline Post test & Junior Nursing & 728 & 1.69 & .462 & \multirow{3}{*}{$\begin{array}{c}\text { df } \\
2 \\
1817 \\
1819\end{array}$} & \multirow{3}{*}{1.662} & \multirow{3}{*}{$\begin{array}{l}.190 \\
\text { N.S }\end{array}$} \\
\hline Case & Nursing Institute & 910 & 1.71 & .453 & & & \\
\hline Group & College of Nursing & 182 & 1.76 & .429 & & & \\
\hline
\end{tabular}

Table (10) shows that there was no significant relationship between effectiveness of instructional program on case group and level of education at $\mathrm{P} \geq 0.05$ level.

Table 11: Association between Effectiveness of Instructional Program and Experiences in Nursing of case

\begin{tabular}{|c|c|c|c|c|c|c|c|}
\hline & & $\mathrm{G}$ & & & & & \\
\hline Total domains & Experiences in Nursing & $\mathbf{N}$ & Mean & SD & df & $\mathbf{F}$ & $\underset{P \geq 0.05}{\text { Sig. }}$ \\
\hline \multirow{4}{*}{$\begin{array}{l}\text { Post test } \\
\text { Case } \\
\text { Group }\end{array}$} & $1-5$ years & 546 & 1.70 & .457 & \multirow{5}{*}{$\begin{array}{l}3 \\
1816 \\
1819\end{array}$} & \multirow{5}{*}{3.271} & \multirow{5}{*}{$\begin{array}{l}. \mathbf{0 2 0} \\
\text { S. }\end{array}$} \\
\hline & 6-10 years & 546 & 1.66 & .472 & & & \\
\hline & 11-15years & 364 & 1.74 & .440 & & & \\
\hline & 16 years and more & 364 & 1.75 & .434 & & & \\
\hline & Total & 1820 & 1.71 & .455 & & & \\
\hline
\end{tabular}

The results of table 11 revealed that there were significant relationship between effectiveness of instructional program on case group and their experiences of them in nursing at $\mathrm{P} \geq 0.05$ level.

Table 12: Association between Effectiveness of Instructional Program and Experiences in Endoscopy Unit of

\begin{tabular}{|c|l|c|c|c|c|c|c|}
\hline \multicolumn{2}{|c|}{ Experiences in Endoscopy } & $\mathbf{N}$ & Mean & SD & df & F & $\begin{array}{c}\text { Sig. } \\
\mathbf{P} \geq \mathbf{0 . 0 5}\end{array}$ \\
\hline \multirow{2}{*}{$\begin{array}{c}\text { Total domains } \\
\text { Post test } \\
\begin{array}{c}\text { Case } \\
\text { Group }\end{array}\end{array}$} & $\mathbf{1 - 5}$ & 547 & 1.69 & .463 & 4 & & \\
\cline { 2 - 5 } & $\mathbf{6 - 1 0}$ & 273 & 1.58 & .495 & & \\
\cline { 2 - 5 } & $\mathbf{1 1 - 1 5}$ & 455 & 1.69 & .464 & 1815 & \multirow{2}{*}{13.188} & .000 \\
\cline { 2 - 5 } & $\mathbf{1 6}$ and more & 455 & 1.82 & .388 & 1819 & & \\
\hline
\end{tabular}

Table (12) shows that there was highly significant relationship between effectiveness of instructional program on case group and their experiences in endoscopy unit at $\mathrm{P} \geq 0.05$ level. 
Table 13: Association between Effectiveness of Instructional Program and training Course of case Group

\begin{tabular}{|l|l|c|c|c|c|c|c|c|}
\hline \multicolumn{2}{|c|}{ Training course } & N & Mean & SD & df & df & F & $\begin{array}{c}\text { Sig. } \\
\text { P } \geq \mathbf{0 . 0 5}\end{array}$ \\
\hline $\begin{array}{l}\text { Total domains test } \\
\begin{array}{l}\text { Case } \\
\text { Group }\end{array}\end{array}$ & Yes & 728 & 1.76 & .430 & .016 & $\mathbf{1}$ & & \\
& No & 1092 & 1.68 & .468 & .014 & $\mathbf{1 8 1 8}$ & 13.19 & .000 \\
\cline { 2 - 7 } & Total & 1820 & 1.71 & .455 & .011 & $\mathbf{1 8 1 9}$ & & H.S. \\
\hline
\end{tabular}

Table (13) shows that there was highly significant relationship between effectiveness of instructional program on case group and their training course at $\mathrm{P} \geq 0.05$ level.

\section{Discussion}

Part I: Discussion of Socio-Demographic Characteristics of the Study Sample for (Case and Control Group) (table1).

Throughout the course of data analysis of present study, the findings showed that $30 \%$ of nurses in the case group at age group (30-34 years) while 35\% of nurses in the control group at age group (25-29 years). Present finding is consistent with El-Sheikh, and Abed-Elsatar, (2011) who reported that $66.7 \%$ of nurses were less than 30 years old. In addition, Ali, \& Taha, (2014) reported in their study which carried out in Zagazig

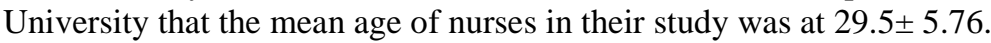

The present study revealed that $65 \%$ of nurses in the case group were males and $55 \%$ of nurses in the control group were males. Moqbel et al., (2015) assess 46 nurses to evaluate the effectiveness of planned health education program on nurses' knowledge and practice for preventing infection in gastrointestinal endoscopy units at major hospitals in Yemen; they reported that more than half of the study sample was female.

The present study revealed that $75 \%$ of the study samples (case and control groups) were married. Imad et al., (2015) presented in their study on 271 nurses assess the level of knowledge and practice of infection control among nurses in governmental hospitals of Palestine, which indicated that the $70 \%$ of study sample were married.

Concerning level of education, most of nurses $50 \%$ of case group were institute graduated, while $80 \%$ of control group graduated from secondary school nursing, the study of Moqbel et al., (2015) presented that the high number of nurses graduated from nursing institute was working in endoscopy unit, the researcher believed It is possible that the low number of university nurses led to the use of professional nurses from nursing schools and nursing graduates in endoscopic units.

In relation to year of experiences in a field of nursing 30\% of a case group have 1-10 years, $40 \%$ of control group have 6-10 years of experience in the field of nursing. Hanan, et al, (2014) presented in their study during assessing 30 nurses to evaluate the knowledge and practice of nursing staff who employed in the gastrointestinal endoscopy center, to determine the nursing intervention for patient having upper endoscopy at gastrointestinal endoscopy center at Assiut University Hospital, they indicated that the 30\% of study sample have 5-10 years of experience.

Concerning the years of experience in the endoscopy $35 \%$ of a case group $1-5$ years, $45 \%$ of a control group have 6-10years of experience in the endoscopy unit, Ali, \& Taha, (2014) presented in their study on 40 nurses, and 5 GIT endoscopes to evaluation the effect of infection control training program on nurse's performance on GIT Endoscopes at Elnaser Insurance Hospital at Helwan City in Egypt, they shows that 57.5 $\%$ of the study sample have more 3 years' experience GIT endoscopy unit.

The present study revealed that $40 \%$ of a case group was participating in a training course related to gastro-endoscopy, and 55\% of a control group was participating in a training course. Amer et al., (2015) evaluated 35 nurses to identify the nurses' knowledge and practice regarding gastrointestinal endoscopy in gastrointestinal endoscopy unit at Zagazig University Hospitals, they presented in their study that the $40 \%$ of nurses have training courses during their work in GIT Endoscopy.

Part II: Discussion of Pre-and Post Nurses' Responses for case and control group regarding to Effectiveness of Instructional Program concerning Preparation of Patients for Gastro-Colonoscopy

The results of the present study revealed that the nurses knowledge for case group which exposed to instructional program were improved at post test for all domains which as changes from 53.6\% them was known at pretest to $70.8 \%$ of them was known about how to prepare patients for gastroscopy at posttest. From the review of Maheswari,and Muthamilselvi, results of their study at (2014) on twenty five Employees working in AVMC hospital, they pointed that over all knowledge at posttest was $93 \%$ are higher than the pretest which as 51\%, and Gijare, (2012) conducted in their study in Pune hospital on 150 nurses working in these hospital to assess the knowledge of Heath Care Professionals about infection control practices before \& after administration of planned health teaching who reported that there is a high significant difference in the all knowledge among nurses during post-test showing that the overall after effect of training was good . 
The researcher believes that the success of the instructional program is due to the nurses' interest in developing their scientific and practical abilities.

The nurses knowledge for control group at pre and post program was changes, although they are not exposed them to instructional program, It is noticeable at most of program domains and total domains which as $47 \%$ of them don't know how to prepare the patients for endoscopy at pre- test and reduces the percent of not known between them to $43.5 \%$ at posttest, this finding is supported by Pathmakanthan et al.,(2001) they presented in their study on 102 nurse endoscopists to determine the prevalence and potential benefits associated with attitudes towards nurse endoscopy in the UK. The significant advancements shown at the post-guidelines program period indicate these nurses were in real need for such information. Furthermore, the acquired knowledge was maintained without declines. The effect of the intervention was verified through statically analysis that recognized this program attendance as a strong positive independent predictor of the knowledge score. The finding further indications that the nurses continuously use their knowledge and use it with their daily practice, which helps recall and memorization. In addition, it shows that these wanted to learn and find out about right information regarding this practice of daily work. This eagerness to learn might be described by the actual fact that many nurses believe that the importance of the provided guidelines for nurses as well as competence of the procedure; however, feel it is required in some situations for the safe practices of the patient.

Tina et al., (2001) presented in their study that a research-based teaching program was effective, and a significant improvement was observed in knowledge and practice after implementation of the teaching protocol, and the nurses' knowledge score levels regarding caring of patient having upper gastroinestinal endoscopy were significantly increased.

The opinion of researcher concerning the changes of control group knowledge as a result of nurses' orientation about the domains of instructional program and the acquisition of knowledge, which was evident in the post-test.

Part III: Discussion the Effectiveness of Instrucional Program regarding Socio-Demoghraphic Characteristics of the Study Sample

Present study findings revealed that there was not significant relationship between effectiveness of instructional program on case group and their level of education at $\mathrm{P} \geq 0.05$, Hanan et al., (2014) revealed in their study that there were not significant relationship between level of education and their education program.

The researcher believed that the present finding might be due to high percent of the study sample graduated from secondary school nursing.

There were significant relationships between effectiveness of instructional program on case group and their experiences of them in nursing at $\mathrm{P} \geq 0.05$ levels and highly significant relationship between effectiveness of instructional program on case group and their experiences in endoscopy unit at $\mathrm{P} \geq 0.05$ level. This finding disagrees with study done by Amer et al., (2015) presented in their study that there were no statistical significance differences between education program and the years of experience of their study sample at $\mathrm{P}$ value 0.119 .

The opinion of researcher that the role of year of experiences of nurse can be effect on the understanding and reviewing their knowledge and therefore the effect on program

Present study revealed that there was highly significant relationship between effectiveness of program on case group and their training course at $\mathrm{P} \geq 0.05$ level, Morse (2010) stated that the nurses continuing education programs helps these to improve both their knowledge and skills. Continuing education helps that nurses are maintain current with new knowledge, skills and information. Batrof, and Mansour, (2012) agreement with our study and who demonstrated that, continuing education must to maintain competence in practice. Education might take the proper executing of on the-job training, programs, workshops or conferences that education has a significant impact on the knowledge and competencies of the nurse. In additional Abd-Alla (2010) reported that the in-service training has an advantageous effect in increasing the nurse's knowledge and skills. In addition, they recommended that educational programs should be arranged in line with the needs of nurses with ongoing evaluation. Also, Friese et al. (2012) who demonstrated that, continuing education must bring about in practice change to be effective. Integration of knowledge occurs when information is combined with performance

The researcher considered that training course will provided the necessary knowledge and skills to enable the nurses to preparation of patients for gastro-colonoscopy.

\section{Conclusions}

\section{The study concluded the following}

1) Nurse's responses for pre-case and pre-control for total domains about their knowledge toward preparation of patients for gastro-colonoscopy were nearest level.

2) Nurse's knowledge for case group at posttest was improved compare with control group.

3) Improvement of nurses' knowledge who graduated from nursing institute at posttest instructional program. 
4) The nurse's knowledge was improved at posttest of instructional program on nurses who have 1-5 year of experiences in nursing.

5) Improvement of nurse's knowledge at posttest of instructional program for nurses who participated in training course.

6) There were significant relationships between effectiveness of instructional program on case group and their experiences of them in nursing, and experiences in endoscopy units at $\mathrm{P} \geq 0.05$ level.

7) Highly significant relationship between effectiveness of instructional program on case group and their training course at $\mathrm{P} \geq 0.05$ level.

\section{Recommendations}

Based on the conclusions of the present findings the researcher can recommend the following:

1) Great emphasis should be directed toward the educational aspects at endoscopy unit by providing educational posters, guidelines, pamphlets and manuals.

2) Encourage to engage nurses by ministry of health for training course

3) Policy should be initiated to providing a special educational session for gastro-colonoscopy nurses'.

4) Modern educational facilities for nursing team at endoscopy unit should be provided to enhance nurses' knowledge.

\section{References}

[1] Yeung, Ka-man, Carmen.; The use of written information to relieve anxiety in patients undergoing endoscopy (2011) http://hdl.handle.net/10722/143205

[2] Prasad J. Athreya, Gareth N. Owen, Shing W. Wong, et al. Achieving quality in colonoscopy: bowel preparation timing and colon cleanliness. ANZ J Surg.2011; 81:261-5.

[3] Salfiti N, and Nelson DB (2008): Infection Control Measures in Gastrointestinal Endoscopy U S Surgery GASTROINTESTINAL ENDOSCOPY Volume 67, No. 6: 2008 www.giejournal.org

[4] Barlow DE. The video colonoscope. In: Rex DK, Way JD, Williams CB, editors. Colonoscopy. London: Blackwell Sciences; 2003.

[5] Lagares -Garcia JA, Kurek S, Collier B, Diaz F, Schilli R, Richey J and Moore RA(2001):Colonoscopy in octogenarians and older patients. Surg Endosc 15:261-5.

[6] Clarke G, Jacobson B, Hammett R and Carr-locke D (2001): The indications, utilization and safety of gastrointestinal endoscopy in an extremely elderly patient cohort. Endoscopy 33:580-4.

[7] Gannon CJ, Malone DL, Royal RE, Schreiber M, Bass BL and Napolitano LM (2002): Advanced proximal colon cancer. Surg Endosc 16(3):446-9.

[8] El-Sheikh, A. A., \& Abed elsatar, O. A. (2011). The effect of implementing a control action plan for infection prevention at endoscopy unit. Egyptian Journal of Nursing, 1(3), 64-84

[9] Ali, Z. H., \& Taha, N. M. (2014). Effect of Infection Control Training Program on Performance and Microbial Results on GIT Endoscopes. Advances in Life Science and Technology, 27, 6-16.

[10] Abdulrahman Ali Moqbel, Amani Mohammed Shebl and Hanan Mohamed Soliman : Effectiveness of Planned Health Education Program on Nurses' Knowledge and Practice for Preventing Infection in Gastrointestinal Endoscopy Units at Major Hospitals in Yemen, Journal of Nursing and Health Science ,(IOSR-JNHS) e-ISSN: 2320-1959.p- ISSN: 2320-1940 Volume 4, Issue 6 Ver. VI (Nov. - Dec. 2015), PP 39-47.

[11] Imad Fashafsheh, Ahmad Ayed, Faeda Eqtait and Lubna Harazneh Knowledge and Practice of Nursing Staff towards Infection Control Measures in the Palestinia Hospitals ,Journal of Education and Practice ISSN 2222-1735 (Paper) ISSN 2222-288X (Online) Vol.6, No.4, 2015 www.iiste.org

[12] Hanan Abd EL-Razik Abd El- All Mohamad, Zienab Abd El-Lateef Mohamad and Zain El-Abdeen Ahmed sayed. "Esophagogastroduodenoscopy": Impact of a designed nursing teaching protocol on nurse's performance and patient's outcome . J Am Sci 2014;10(10):56-65]. (ISSN: 1545-1003). http://www.jofamericanscience.org

[13] Amer et al., Afro-Egypt J Infect Endem Dis 2015; 5(2): 115-130 http://mis.zu.edu.eg/ajied/home . aspx

[14] Maheswari, S. and Muthamilselvi, G., " Assess the Effectiveness of Structured Teaching Programme on Universal Precaution among Class IV Employees Working at Aarupadai Veedu Medical College and Hospital, Puducherry, India.” American Journal of Nursing Research, vol. 2 , no. 2 ( 2014): 26- 30. doi:10.12691/ajnr-2-2-3.

[15] Gijare, M. (2012). Effectiveness of teaching on infection control practices among health care professionals. Sinhgad e Journal of Nursing, 2(2), 5-9.

[16] Pathmakanthan S, Murray I, Smith K, Heeley R, Donnelly M. Nurse Endoscopists in United Kingdom health care: a survey of prevalence, skills and attitudes. J Adv Nurs 2001; 36: 70510

[17] Tina Day, and Steven P., Wainwright and Jenifer Wilson-Barnett (2001): An evaluation of a teaching intervention to improve the practice. Journal of Clinical Nursing, Volume (10), Issue(5), p.p 682-696.

[18] Batrof M., and Mansour K.,: Management Principles for Health Professionals, 5th ed, Jones \&Bartlett,Vol II, Philadelphia, Lippincott, Chapter(2), (2012),: p: 141.

[19] Morse, J. M. (2010). What happened to research programs? [Editorial]. Qualitative Health Research, 20, 147. Published, 02/2010.

[20] Friese C., Lake E., Aiken L.and Silber J., (2012): hospital nurse practice environment and outcomes for hepatology patients, Journal of Health Services Research, Vol (43), Issue (4) : 114-117. 